\title{
SHARIA GOVERNANCE DAN KINERJA LEMBAGA KEUANGAN SYARIAH: FIRM SIZE SEBAGAI PEMODERASI
}

\author{
Febri Rahmi, Leny Nofianti, Andi Irfan, dan Desrir Miftah \\ Febri.rahmi@uin-suska.ac.id \\ Fakultas Ekonomi dan Ilmu Sosial UIN Suska Riau
}

\begin{abstract}
Islamic Banking has astrategic rolein improving the welfare of the people, through theintermediation process of lending and funding distribution activities and the provision of other financial services, based on the principles of sharia. The study looked at the relationship between the application of the principles of Shari'ah governance and performance of Islamic financia linstitutions in Riau. In this study, the performance of Islamic banking financial institutions measuredusing the Balanced Scorecard. The research was conducted on Islamic banking institutions in Riau, both Islamic Banks (BUS) and Sharia (UUS) successfully collected the data by 35 respondents. This study shows that sharia governance is able to influence the performance of sharia financial institutions in Riau Province as evidenced by a coefficient of 5.008 with a significance level of 0.000 much smaller than the value of $\alpha(0.05)$. The results of this next study indicate that sharia governance is not able to influence the performance of Islamic financial institutions in Riau Province after being moderated by firm size as evidenced by a coefficient of -1.933 with a significance level of 0.071 greater than the value of $\alpha(0.05)$.
\end{abstract}

\section{Keywords: Banking and Islamic Institutions, Sharia Governance}

\begin{abstract}
Abstrak
Perbankan Syariah memiliki peran strategis dalam meningkatkan kesejahteraan umat, melalui proses intermediasi kegiatan penghimpunan dan penyaluran dana maupun penyediaan jasa keuangan lainnya, berlandaskan kepada prinsip-prinsip syariah.Penelitian ini hubungan antara penerapan model prinsip governance syari'ah dengan kinerja lembaga keuangan syariah di Riau. Pada penelitian ini kinerja lembaga keuangan perbankan syariah diukur dengan mengunakan Balanced Scorecard. Penelitian ini dilakukan pada lembaga perbankan Syariah di Riau, baik Bank Umum Syariah (BUS) maupun Unit Usaha Syariah (UUS) berhasil dikumpul data sebanyak 35 responden. Penelitian ini menunjukkan bahwa sharia governance mampu mempengaruhi kinerja lembaga keuangan syariah di Provinsi Riau yang dibuktikan dengan koefisien sebesar 5,008 dengan tingkat signifikansi sebesar 0,000 jauh lebih kecil
\end{abstract}


dibandingkan dengan nilai a (0,05). Hasil penelitian berikutnya ini menunjukkan bahwa sharia governance tidak mampu mempengaruhi kinerja lembaga keuangan syariah di Provinsi Riau setelah dimoderasi oleh firm size dibuktikan dengan koefisien sebesar -1,933 dengan tingkat signifikansi sebesar 0,071 lebih besar dibandingkan dengan nilai $\alpha(0,05)$.

\section{Keywords: Perbankan dan Lembaga Keuangan Syariah, kinerja, Governance Syariah}

\section{PENDAHULUAN}

Kemampuan survival perbankan syariah dalam era krisis membuktikan bahwa perbankan syariah mampu menyelamatkan sebagian ekonomi ummat. Perbankan syariah melalui proses intermediasi kegiatan penghimpunan dan penyaluran dana maupun penyediaan jasa keuangan lainnya, berlandaskan kepada prinsip-prinsip syariah memiliki peran strategis dalam meningkatkan kesejahteraan umat. Hal ini juga yang menjadi daya tarik banyak para bankir konvensional yang kemudian membuka kantor-kantor cabang syariah.

Selama tahun 2013, perbankan syariah Indonesia mengalami salah satu masa pertumbuhan tertinggi, market share perbankan syariah dalam peta perbankan sehingga mencapai $\pm 4,8$ persen per Oktober 2013 , dengan jumlah rekening di perbankan syariah mencapai \pm 12 juta rekening atau 9,2 persen dari total rekening perbankan nasional serta jumlah jaringan kantor mencapai 2.925 kantor. Khususnya Eropa dan Amerika masih dibayangi perlambatan pertumbuhan, Bank Indonesia memperkirakan perekonomian Indonesia di tahun depan masih tetap mengalami pertumbuhan yang cukup tinggi dalam kisaran 6,3\% - 6,7\%. Dengan demikian diharapkan dampak krisis ekonomi kepada tingkat pertumbuhan perbankan syariah cenderung minimal, terlebih dengan tidak banyaknya portofolio aset perbankan syariah dalam valuta asing maupun di luar negeri. (Outlook Perbankan Syari'ah, 2013).

Bukti bahwa Bank Syariah memiliki peranan lebih besar dalam menjalankan fungsi intermediasi juga terlihat dari peningkatan perbankan syariah di Indonesia dari tahun ketahun dibandingkan perbankan umum, Fungsi intermediasi perbankan terus berjalan dengan baik dengan FDR di atas $100 \%$. Pembiayaan produktif (modal kerja dan investasi) terus meningkat melebihi $70 \%$ dari total pembiayaan yang disalurkan oleh perbankan syariah. Sebaliknya pembiayaan consumer semakin melambat seiring dengan meningkatkannya pembiayaan produktif. Di masa depan, kemungkinan terjadinya korupsi dan penyimpangan di bank syari'ah merupakan hal tidak mustahil, meskipun di sana ada Dewan Pengawas Syari'ah, karena para pelakunya bukan malaikat. Apalagi sekarang ini perbankan syari'ah semakin banyak, maka para bankir syari'ah pun semakin bertambah banyak pula. Sehubungan dengan itu para jajaran eksekutif dan pejabat bank, bahkan termasuk komisaris harus ekstra hati-hati dalam mengelola lembaga perbankan syariah yang selalu dinilai "suci", karena berasal dari prinsip 
ilahiyah. Untuk itu perlu penerapan tata kelola perusahaan yang baik (Good Corporate Governance)yang sesuai dengan ajaran Islam.

Perkembangan Perbankan Syariah yang begitu pesat akhir-akhir ini menuntut segera diimplementasikannya praktik-praktik Good Corporate Governance(GCG) dalam pengelolaan perbankan agar dapat memberikan perlindungan yang maksimum kepada semua pihak yang berkepentingan dalam stakeholder, terutama nasabah atau deposan. Disamping itu penerapan GCG dapat membantu bank syariah meminimalisasi kualitas pembiayaan yang tidak baik, meningkatkan akurasi penilaian bank, infrastruktur, kualitas pengambilan keputusan bisnis, dan mempunya sistem deteksi dini terhadap high risk business area, product, dan services.

IICG (The Indonesian Institute for Corporate Governance; 2000) mendefinisikan konsep Corporate Governance sebagai serangkaian mekanisme untuk mengarahkan dan mengendalikan suatu perusahaan agar operasional perusahaan berjalan sesuai dengan harapan para pemangku kepentingan (stakeholders). Definisi tersebut mengandung kesimpulan bahwa Corporate Governance merupakan serangkaian mekanisme, yang mana mekanisme tersebut terdiri dari struktur, sistem dan proses yang digunakan oleh organ-organ dalam perusahaan untuk mengarahkan dan mengendalikan operasional perusahaan agar berjalan sesuai dengan apa yang diharapkan.

Jika dibanding dengan para bankir konvensional, maka bankir syari'ah seharusnya lebih unggul dan terdepan dalam implementasi GCG di lembaga perbankan, mengingat lembaga perbankan syari'ah membawa nama agama ke dalam lembaga bisnis. Tegasnya, bankir syari'ah harus memainkan perannya sebagai pionir penegakan GCG di lembaga perbankan. Jika para bankir syari'ah melakukan penyimpangan dan moral hazard, hal itu tidak saja berimplikasi kepada lembaga tersebut tetapi juga kepada citra syari'ah. Meskipun masyarakat mengetahui bahwa hal itu kesalahan oknum tertentu. Tetapi orang akan dengan cepat menilai bahwa lembaga syariah saja melakukan moral hazard, apalagi lembaga konvensional.

Permasalahan yang terjadi ketika penerapan prinsip governance di Perbankan Syariah disamakan dengan prinsip governance di Perbankan Konvensional. Menurut Algoud dan Lewis (1999) permasalahan governance dalam perbankan syariah ternyata sangat berbeda dengan perbankan konvensional. Hal ini disebabkan oleh bank syariah memiliki kewajiban untuk mematuhi prinsip syariah (syari'ah complience) (Algoud dan lewis, 2001), kemungkinan terjadinya asimetri informasi sangat tinggi bagi perbankan syariah (Archer dan kariim, 1997), dan karena perbankan syariah sebaiknya menjadi karakter inheren berupa etika bisnis yang Islami (Sigit Pramono, 2002). Abdussalam Mahmoud Abu-Tapanjeh (2009) meneliti mengenai sifat, aplikasi dan perbandingan prinsip tata kelola (governance) perusahaan Islam dengan prinsip-prinsip Tata kelola perusahaan yang dikemukakan oleh OECD (The Organization for Economic Co-operation and Development) yang konvensional. Penelitian tersebut menyimpulkan bahwa dimensi perspektif Islam yaitu corporate governance memiliki cakrawala yang lebih luas dan tidak 
dapat dikotakkan peran dan tanggung jawab, dimana semua tindakan dan kewajiban berada di bawah yurisdiksi hukum ilahi Islam, tetapi masih menerapkan prinsip-prinsip OECD yang berbeda masalah dan kewajiban.

Nofianti, et.al (2012) menggali dan mengembangkan prinsip Good Corporate Governance(GCG) Syariah yang bisa mencerminkan governance Syariah, dengan merujuk dari masa kepemimpinan Rasulullah SAW dan Khulafahul Ryashidin. Islam jauh mendahului kelahiran GCG yang menjadi acuan bagi tata kelola perusahaan yang baik di dunia, ada beberapa prinsip yang dianggap penting bagi peneliti dalam menerapkan Good Corporate Governance Syariah. Untuk menerapkan GCG pada perbankan syariah, tidak cukup hanya dengan prinsip governance yang dikemukakan untuk bank konvensional. Ada beberapa prinsip yang harus melekat pada usaha syariah. Pada penelitian berikutnya, peneliti (Nofianti, et.al: 2013) berhasil membuktikan bahwa ada hubungan antara penerapan model prinsip governance syari'ah dengan kinerja lembaga keuangan syariah di Riau.

Pada penelitian ini dengan prinsip governance sharia yang telah diteliti pada penelitian sebelumnya, peneliti mencoba melanjutkan penelitian dengan memasukkan faktor lain berupa firm size (ukuran perusahaan) sebagai variabel pemoderasi pada lembaga keuangan syariah. Perusahaan yang besar didukung oleh kapitalisasi yang besar membutuhkan tata kelola yang baik (Good Governance) untuk mencapai kinerja yang baik. Darmawati (2004) menyatakan bahwa perusahaan besar pada dasarnya memiliki kekuatan finansial yang lebih besar dalam menunjang kinerja, tetapi disisi lain,perusahaan dihadapkan pada masalah keagenan yang lebih besar.

\section{I.1. Perumusan Masalah}

Berdasarkan latar belakang di atas dapat dirumuskan masalah sebagai berikut:

1. Apakah terdapat pengaruh tata kelola syariah (sharia governance) dengan kinerja lembaga keuangan syariah di Provinsi Riau

2. Apakah firm size mampu memoderasi antara sharia governance dan kinerja lembaga keuangan syariah di Provinsi Riau.

\section{I.2. Tujuan dan Manfaat Penelitian}

Tujuan yang ingin dicapai pada penelitian ini adalah:

1. Untuk menganalisis pengaruh sharia governance dengan kinerja lembaga keuangan syariah di Riau.

2. Untuk menganalisisapakah firm size mampu memoderasi antara sharia governance dan kinerja lembaga keuangan syariah di Riau. Manfaat penelitian ini adalah:

1. Bagi lembaga keuangan syariah, dapat memecahkan permasalahan yang dihadapi berkaitan dengan penerapan sharia governance

2. Sebagai bahan pengembangan ilmu yaitu integrasi ilmu ekonomi konvensional dengan ilmu keIslaman terutama mengenai governance sharia. 


\section{KERANGKA TEORITIS DAN PENGEMBANGAN HIPOTESIS \\ II.1. Governance Theory}

Teori Governance dikemukakan oleh Stoker (1998) mengemukakan bahwa: Governance refers to the development of governing styles in which boundaries between and within public and private sectors have become blurred. The essence of governance is its focus on mechanisms that do not rest on recourse to the authority and sanctions of government...,Governance for (some) is about the potential for contracting, franchising and new forms of regulation. In short, it is about what (some) refer to as the new public management. However, governance, ...is more than a new set of managerial tools. It is also about more than achieving greater efficiency in the production of public services (1998, $p$. 17-18). Menurut Stoker (1998) governance merupakan perkembangan dari gaya pemerintahan, yang mana batas antara sektor publik dan sektor swasta sudah kabur. Esensi governance difokuskan pada mekanisme yang tidak bergantung pada penggunaan otoritas dan sanksi dari pemerintah, governance merupakan bentuk baru dari peraturan menuju New Public Management (NPM). Governance merupakan lebih dari satu set alat manajerial untuk mencapai pelayanan publik yang lebih baik.

Berdasarkan definisi di atas, maka pengertian corporate governance cukup luas karena mencakup hubungan antara manajemen perusahaan dengan pemiliknya dan para pemilik kepentingan lainnya, dan juga mengemukakan tentang keselarasan tujuan antara manajemen dengan pemilik, insentif, pemantauan dan pengendalian. Di Indonesia, bank syariah untuk menerapkan GCG selain membutuhkan dewan komisaris dan komite audit, juga harus terdapat dewan pengawas syariah. Dewan pengawas syariah ini merupakan pihak luar perusahaan yang kemudian menjadi bagian dari internal perusahaan yang diangkat dengan persetujuan Dewan Syariah Nasional.

\section{II.2. Prinsip Governance Konvensional}

Secara yuridis prinsip-prinsip GCG yang telah ditetapkan oleh BI dalam Peraturan Bank Indonesia (PBI) No. 8/4/PBI/2006 dan diubah dalam Peraturan Bank Indonesia No. 8/14/PBI/2006 tentang Pelaksanaan Good Corporate Governance bagi Bank Umum. Didalam Undang-Undang No 21 Tahun 2008 tentang Perbankan Syariah, ditentukan bahwa dalam melaksanakan usahanya, bank syariah dan Unit Usaha Syari'ah) UUS wajib memenuhi tata kelola perusahaan yang baik (good corporate governance), prinsip kehati-hatian dan pengelolaan risiko. Selain itu bank syari'ah dan UUS diwajibkan pula untuk menerapkan prinsip mengenal nasabah dan perlindungan nasabah termasuk kewajiban untuk menjelaskan kepada Nasabah mengenai kemungkinan timbulnya risiko kerugian sehubungan dengan transaksi nasabah yang dilakukan melalui Bank Syariah. (Undangundang No. 21 Tahun 2008, tentang Perbankan Syariah, pasal 34, 35, 38 dan 39) 
Peraturan Bank Indonesia Tentang Pelaksanaan Good Corporate Governance Bagi Bank Umum Nomor:8/4/PBI/2006 tanggal 30 Januari 2006) mengatakan bahwa: Good Corporate Governance adalah suatu tata kelola Bank yang menerapkan prinsip-prinsip keterbukaan (transparancy), akuntabilitas (accountability), pertanggungjawaban (responsibility), independensi (independency), dan kewajaran (fairness).

\section{II.3. Prinsip Governance Sharia}

Beberapa prinsip yang dianggap penting dalam menerapkan Governance Sharia, dan implementasi dalam perbankan syariah sebagai berikut: [1]. Shiddiq (Kejujuran) artinya benar dalam perkataannya dan perbuatannya. Bahwa Rasulullah dalam perkataan dan perbuatannya seperti tertera dalam Surah An Najm 4-5 "Dan tiadalah yang diucapkannya itu (Al Qur'an) menurut kemauan hawa nafsunya. Ucapannya itu tiada lain hanyalah wahyu yang diwahyukan kepadanya". [2]. Amanah (Pemenuhan Kepercayaan) artinya benar-benar bisa dipercaya. Jika satu urusan diserahkan kepadanya, niscaya orang percaya bahwa urusan itu akan dilaksanakan dengan sebaik-baiknya. "Aku menyampaikan amanat-amanat Tuhanku kepadamu dan aku hanyalah pemberi nasehat yang terpercaya bagimu." (Al A'raaf: 68. [3]. Tabligh (Transparansi dan Keterbukaan) artinya menyampaikan. Tidak ada yang disembunyikan meski itu menyinggung. [4]. Fathonah (Kecerdasan) artinya cerdas dalam menyampaikan, menjelaskan, mengatur dan mengelola sesuatu. [5]. Tawazun (Keseimbangan) adalah keseimbangan dalam segala hal dan ini merupakan karakter dari ahlusunnah wal jamaah yang selalu diajarkan oleh Nabi Muhammad SAW dan para sahabat. [6]. Mas'uliyah (Akuntabilitas) adalah akuntabilitas yang merupakan prinsip kepemimpinan. [7]. Akhlaq (Moral dan Integritas) merupakan suatu tindakan yang mendorong seseorang untuk bertindak secara baik.[8]. 'Adalah (Keadilan) merupakan keadilan dalam bersikap. Dari dasar mekanisme keuangan syari'ah tersebut akan mampu mewujudkan kegiatan ekonomi yang lebih adil dan transparan. [9]. Hurriyah (Independensi dan Kebebasan yang Bertanggungjawab) adalah sikap yang beranggapan bahwa manusia merupakan ciptaan Tuhan dan memiliki kebebasan yang bertanggung jawab. [10]. Ihsan (Profesional) adalah kesempurnaan atau terbaik, profesional dalam menjalankan tugas. [11]. Wasathan (Kewajaran) adalah kewajaran dalam segala hal. [12]. Ghirah (Semangat) adalah semangat dalam membela yang benar. [13]. Idarah (Pengelolaan) adalah mampu mengelola semua hal dengan baik. [14]. Khilafah (Kepemimpinan) adalah kepemimpinan dalam Islam, mampu memimpin secara keseluruhan. [15]. Aqidah (Kepercayaan dan Keyakinan) adalah kepercayaan dan keyakinan yang teguh. [16]. Ijabiyah (Berfikir Positif) adalah berfikir positif dan tidak menganggap sesuatu hal menjadi tidak penting. [17]. Raqabah (Pengawasan) adalah prinsip yang menganggap bahwa setiap tindakan itu diawasi. [18]. Qira'ah Dan Ishlah yaitu organisasi yang terus belajar dan selalu melakukan perbaikan). [19]. Zuhud (menghindari hal-hal keduniawian) adalah 
menganggap bahwa dunia bukan segala-galanya tetapi ada akhirat yang kekal.(Nofianti dkk, 2011)

\section{II.4. Kinerja Lembaga Keuangan Perbankan Syariah}

Pelaksanaan sharia governance yang baik dan sesuai dengan peraturan yang berlaku akan membuat investor memberikan respon positif terhadap kinerja perusahaan dan nilai pasar perusahaan. Pengertian kinerja adalah gambaran pencapaian pelaksanaan suatu kegiatan atau program atau kebijaksanaan dalam mewujudkan sasaran, tujuan, misi dan visi organisasi. Kinerja perusahaan dipengaruhi oleh beberapa faktor, antara lain terkonsentrasi atau tidaknya terkonsentrasinya kepemilikan, manipulasi laba, serta pengungkapan laporan keuangan.

Kinerja perusahaan dapat dilihat dari aspek keuangan dan juga aspek non-keuangan. Dari aspek keuangan dapat dilihat dari laporan keuangan yang menggambarkan bagaimana kinerja keuangan dalam suatu perusahaan dan sering menjadi perhatian utama bagi para pemakai informasi laporan keuangan. Sedangkan dari aspek non-keuangan bisa dilihat dari kepuasan nasabah ataupun perkerja, dan juga bisa dilihat dari perkembangan aktivitas bisnis perusahaan dan lain sebagainya. Salah satu cara untuk menilai kinerja pada bank adalah melalui tingkat kesehatannya. Untuk bank syariah telah dikeluarkan Peraturan Bank Indonesia Nomor 9/1/PBI/2007 dan Surat Edaran Bank Indonesia Nomor 9/24/DPBS tentang Sistem Penilaian Tingkat Kesehatan Bank Umum Berdasarkan Prinsip Syariah.

Pada penelitian ini kinerja lembaga keuangan perbankan syariah diukur dengan mengunakan Balanced Scorecard. Balanced Scorecard merupakan konsep manajemen kinerja kontemporer yang mulai banyak diaplikasikan pada organisasi publik. Balanced Scorecard dinilai tepat untuk organisasi publik, karena Balanced Scorecard tidak hanya menekankan pada aspek kuantitatif dan finansial, tetapi juga aspek kualitatif dan non finansial. Balanced Scorecard pertama kali diperkenalkan oleh Kaplan dan Norton (1996:102) yang dilandasi oleh revolusi teknologi informasi dan persaingan usaha yang semakin turbulen (berubah-ubah). Secara umum hal yang berkaitan dengan Balanced Scorecard, berikut: [1]. Merupakan penerjemahan dari visi, misi organisasi ke dalam strategi. [2]. Menetapkan ukuran kinerja melalui mekanisme komunikasi antar tingkatan manajemen. [3]. Mengevaluasi hasil kinerja secara terus menerus guna perbaikan pengukuran kinerja pada kesempatan selanjutnya. Balanced Scorecard menterjemahkan misi dan strategi ke dalam berbagai tujuan dan ukuran yang tersusun ke dalam empat perspektif, yaitu: Financial, Customers and stakeholders, Internal bussiness process, Employess and organization capacity. Balanced Scorecard membuat keseimbangan antara berbagai ukuran kinerja yaitu keseimbangan antara ukuran kinerja keuangan dan non keuangan, ukuran kinerja masa lalu (lag indicator) dan masa depan (lead indicator) dan ukuran kinerja internal dan eksternal. 


\section{II.5. Firm Size (Ukuran Perusahaan)}

Ukuran perusahaan merupakan nilai yang menunjukkan besar kecilnya perusahaan. Terdapat berbagai proksi yang biasanya digunakan untuk mewakili ukuran perusahaan, yaitu jumlah karyawan, total aset, jumlah penjualan, dan kapitalisasi pasar (Dini dan Djoko, 2012). Ukuran perusahaan merupakan hal yang penting dalam proses pelaporan keuangan. Ukuran perusahaan dalam penelitian ini diukur dengan melihat seberapa besar asset yang dimiliki oleh sebuah perusahaan. Aset yang dimiliki perusahaan ini menggambarkan hak \& kewajiban serta permodalan perusahaan. Darmawati (2004) menyatakan bahwa perusahaan besar pada dasarnya memiliki kekuatan finansial yang lebih besar dalam menunjang kinerja, tetapi disisi lain, perusahaan dihadapkan pada masalah keagenan yang lebih besar.

\section{II.6. Pengembangan Hipotesis}

Keharusan tampilnya bankir syari'ah sebagai pionir penegakan GCG dibanding konvensional, menurut Algaoud dan Lewis (2009) karena permasalahan governance dalam perbankan syariah ternyata sangat berbeda dengan bank konvensional. Pertama, bank syariah memiliki kewajiban untuk mematuhi prinsip-prinsip syariah (sharia compliance) dalam menjalankan bisnisnya. Karenanya, Dewan Pengawas Syariah (DPS) memainkan peran yang penting dalam governance structure perbankan syariah. Kedua, karena potensi terjadinya information asymmetry sangat tinggi bagi perbankan syariah maka permasalahan agency theory menjadi sangat relevan. Hal ini terkait dengan permasalahan tingkat akuntabilitas dan transparansi penggunaan dana nasabah dan pemegang saham. Karenanya, permasalahan keterwakilan investment account holders dalam mekanisme good corporate governance menjadi masalah strategis yang harus pula mendapat perhatian bank syariah (Archer dan Karim, 1997). Ketiga, dari perspektif budaya korporasi, perbankan syariah semestinya melakukan transformasi budaya di mana nilainilai etika bisnis Islami menjadi karakter yang inheren dalam praktik bisnis perbankan syariah (Sigit Pramono, 2002).

Menurut Beikos dan Cyprus dalam Rindaasytuti (2000) disamping itu bank syariah menghadapi risiko keuangan yang lebih besar dibandingkan dengan bank konvensional karena pertama, sebagian besar pembiayaan di bank syariah adalah bagi hasil dimana pendapatan bank dari bagi hasil ini memiliki tingkat risiko lebih tinggi. Kedua, bank syariah menanggung risiko likuiditas yang lebih besar karena sejumlah asetnya adalah bentuk asset non likuid. Ketiga bank syariah lebih terekspos pada risiko perubahan fiscal dan moneter karena penerapan pembiayan bagi hasil kepada nasabahnya, keempat bank syariah mempunyai risiko lebih besar pada resiko nilai tukar karena dilarang melakukan hedging.

Risiko yang dihadapi oleh perbankan syariah adalah risiko kredit (aset non bagi hasil, dan asset sistim bagi hasil (asset variable), risiko pasar (risiko harga ekuitas, risiko nilai tukar, risiko harga komoditas, risiko likuiditas, risiko operasional, risiko hukum, risiko reputasi dan lain-lain. Dimana risiko-risiko 
ini harus diminimalisir oleh manajemen guna mengingkatkan kinerja bank syariah. Salah satu yang dapat dilakukan adalah penerapan sharia governance. Risiko di Perbankan Syariah adalah sebagai salah satu faktor yang dapat mendorong pelaksanaan corporate governance di bank syariah.

Abdussalam Mahmoud Abu-Tapanjeh (2009) meneliti mengenai sifat, aplikasi dan perbandingan prinsip tata kelola perusahaan Islam dengan prinsip-prinsip tata kelola perusahaan yang dikemukakan oleh OECD yang konvensional. Penelitian tersebut menyimpulkan bahwa dimensi perspektif Islam corporate governance memiliki cakrawala yang lebih luas dan tidak dapat dikotakkan peran dan tanggung jawab, di mana semua tindakan dan kewajiban jatuh di bawah yurisdiksi hukum ilahi Islam tetapi masih menerapkan prinsip-prinsip OECD yang berbeda masalah dan kewajiban. Zulkifli Hasan (2009) menyimpulkan bahwa Sharia Governance memiliki keunikan bila dibandingkan dengan konvensional.

Aznan (2002) membahas Models of Shariah Governance di beberapa negara seperti Malysia, Pakistan, U.A.E, Bahrain, Kuwait dan Qatar. Maria Bhatti and M. Ishaq Bhatti (2010) mengusulkan model Islamic Corporate Governance (ICG) yang menyatukan tujuan hukum syariah dengan model stakeholder tata kelola perusahaan. Ini berpendapat bahwa ini mungkin layak adanya penekanan yang menempatkan hukum syariah di properti dan hakhak kontraktual keuangan Islam. Kemudian Setyani (2010) meneliti kebijakan pemerintah tentang pelaksanaan Good Corporate Governance bagi Bank Umum dalam praktek perbankan syariah di Indonesia dan mengkaji implementasi Good Corporate Governance bagi bank umum dalam pengelolaan perbankan syariah di Indonesia.

Hutagalung (2004) berhasil membuktikan bahwa penerapan prinsipprinsip good corporate governance mempunyai pengaruh yang signifikan terhadap kinerja keuangan BUMN di Indonesia. Di samping itu, penerapan prinsip-prinsip good corporate governance mempengaruhi sumber keunggulan internal maupun eksternal dari BUMN. Dalam penelitian ini, Hutagalung menggunakan 63 BUMN sebagai sampel dan kinerja keuangannya dilihat dari tingkat pertumbuhan ROA (return on asset)-nya.

Penelitian Che Hat et al (2008) menemukan bahwa penerapan Good Corporate Governance memiliki pengaruh yang signifikan terhadap kinerja perusahaan. Dengan mengunakan proksi sharia governance, Nofianti dkk (2013) dapat membuktikan bahwa ada hubungan antara penerapan sharia governance dengan kinerja lembaga keuangan syariah di Riau. Jadi, dengan penerapan sharia governance yag dimiliki semakin oleh lembaga keuangan syariah maka kinerja bisa ditingkatkan. Maka hipotesisnya adalah:

\section{H1 : Terdapat pengaruh antara sharia governance dengan kinerja lembaga keuangan syariah di Provinsi Riau}

Hesti (2010) dan Uyun (2010) dalam penelitiannya menemukan bukti bahwa ukuran perusahaan berpengaruh positif signifikan terhadap kinerja keuangan perusahaan. Perusahaan dengan aset besar biasanya akan 
mendapatkan perhatian lebih dari masyarakat. Hal ini akan menyebabkan perusahaan lebih berhati-hati dalam melakukan pelaporan keuangannya. Perusahaan diharapkan akan selalu berusaha menjaga stabilitas kinerja keuangan mereka. Pelaporan kondisi keuangan yang baik ini tentu tidak serta merta dapat dilakukan tanpa melalui kinerja yang baik dari semua lini perusahaan. Perusahaan besar yang memiliki tata kelola baik akan memiliki kapitalisasi besar sehingga kinerja lembaga keuangan syariah akan semakin baik. Maka hipotesisnya adalah:

H2: Ketika firm size semakin besar akan mampu memoderasi antara sharia governance dan kinerja lembaga keuangan syariah di Provinsi Riau

\section{METODE PENELITIAN}

\section{III.1. Lokasi Penelitian}

Penelitian ini dilakukan pada lembaga perbankan Syariah di Riau, baik Bank Umum Syariah (BUS) maupun Unit Usaha Syariah (UUS). Kemudian penelitian ini dirancang untuk memperoleh gambaran tentang hubungan antara model governance syariah dengan kinerja lembaga keuangan syariah. Metode penelitian yang digunakan dalam penelitian ini adalah metode survey, yaitu penelitian yang mengambil sampel dari satu populasi dan menggunakan kuisioner sebagai alat pengumpul data yang pokok (Masri Singarimbun dan Sofian Efendi, 1989).

\section{III.2. Populasi dan Sampel}

Populasi dalam penelitian ini adalah seluruh lembaga keuangan syariah di Riau. Peneliti memilih Lembaga Perbankan Syariah yang banyak terdapat di beberapa daerah di Riau antara lain Kota Pekanbaru, Kabupaten kampar, Kabupaten Bengkalis dan Indragiri Hilir. Nama-nama Lembaga Perbankan Syariah di Riau tersebut antara lain sebagai berikut:

1. PT Bank Syariah Mandiri

2. PT. Bank Syariah Muamalat Indonesia

3. PT Bank Syariah BNI

4. PT Bank Syariah BRI

5. PT. Bank Syariah Mega Indonesia

6. PT Bank Panin Syariah

7. PT Bank Syariah Bukopin
8. PT Bank Syariah Mandiri

9. PT BCA Syariah

10. PT. Bank Permata Syariah

11. BPRS Sari Madu

12. BMT Bina Swadaya

13. Koperasi Syariah BMT Al-Ittihad

14. Bank Syariah Berkah

15. KKJS BMT UGT Sidogiri Kampar

Dari 35 kuesioner yang disebar di empat Kabupaten yang dipilih, diperoleh 18 kuesioner yang kembali dan dapat diolah.

\section{III.3. Metode Pengumpulan Data}

Data yang digunakan dalam penelitian ini adalah data primer dan data sekunder. Data primer diperoleh dengan membagikan angket atau kuesioner 
kepada responden, sedangkan data sekunder berasal dari laporan dari bank Indonesia.

\section{III.4. OperasionalisasiVariabel}

Adapun variabel-variabel yang diukur dalam penelitian ini adalah sebagai berikut:

1. Variabel Independen (X), yaitu: Good Corporate Governance Syariah. Good Corporate Governance Syariah adalah suatu tata kelola perusahaan yang menerapkan prinsip-prinsip syariah. Variabel Good Corporate Governance Syariah ini diukur dengan instrumen yang dikembangkan oleh Nofianti dkk (2011), dengan dimensi yaitu: Shiddiq (kejujuran), Amanah (Pemenuhan Kepercayaan), Tabliqh (Transparansi dan Keterbukaan), Fathonah (kecerdasan), Tawazun (keseimbangan), Mas'uliyah (akuntabilitas), Akhlaq (Moral dan Integritas), 'Adalah (Keadilan), Hurriyah (Independensi dan Kebebasan yang Bertanggungjawab), Ihsan (Profesional), Wasathan (Kewajaran), Ghirah (Semangat), Idarah (Pengelolaan), Khilafah (Kepemimpinan), Aqidah (Kepercayaan dan Keyakinan), Ijabiyah (Berfikir Positif), Raqabah (Pengawasan), Qira'ah Dan Ishlah (Organisasi Yang Terus Belajar Dan Selalu Melakukan Perbaikan) dan Zuhud (menghindari hal-hal keduniawian)

2. Variabel Dependen (Y), yaitu kinerja lembaga keuangan syariah. Kinerja lembaga keuangan syariah pada penelitian ini diukur dengan instrumen yang digunakan oleh Rohm (2004), kemudian dikembangkan oleh Dikdik Tandika (2009) yang telah diuji validitas dan reliabilitasnya. Selanjutnya instrumen tersebut disesuaikan dengan kondisi riil di lembaga keuangan syariah tersebut. Pengukuran kinerja organisasi yang digunakan dalam penelitian adalah dengan pendekatan balance scorecard. Adapun dinilai dari 4 perspektif, yaitu: Financial, Customers and stakeholders, Internal bussiness process, dan Employess and organization capacity

3. Variabel Moderasi, adalah variabel yang bersifat memperkuat atau memperlemah variabel independen terhadap variabel dependen.

Pada penelitian ini variabel moderasinya adalah ukuran perusahaan lembaga keuangan syariah, yang dilihat dari proksi "jumlah karyawan"

\section{III.5. Desain Penelitian}

\section{Model Penelitiaan}

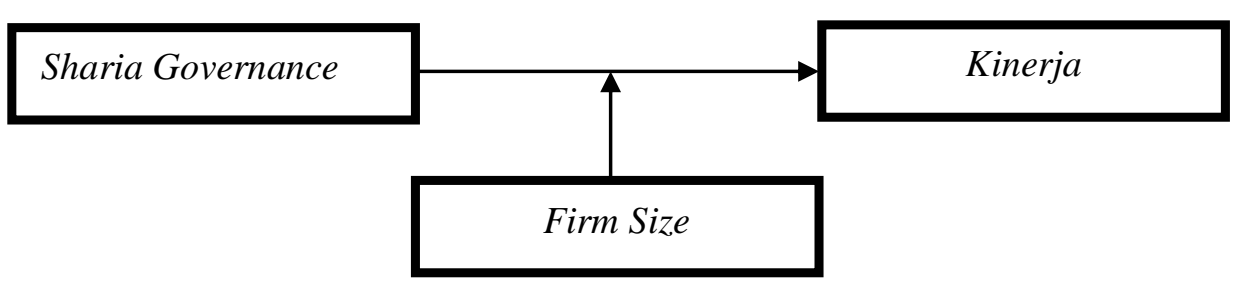




\section{III.6. Teknik Analisis Data}

Analisis data yang meliputi pengujian instrumen (uji validitas dan reliabitas), pengujian data (uji asumsi klasik), dan pengujian hipotesis dilakukan dengan program SPSS for Windows. Pengujian hipotesis penelitian ini dilakukan dengan analisis regresi berganda dengan model sebagai berikut:

$$
\mathrm{Y}=\mathrm{a}+\mathrm{b} 1 \mathrm{X} 1+\mathrm{b} 2 \mathrm{X} 2+\mathrm{b} 3 \mathrm{X} 1 * \mathrm{X} 2+\mathrm{e}
$$

Keterangan:

$$
\begin{array}{ll}
\mathrm{Y} & : \text { Kinerja Lembaga Keuangan Syariah } \\
\mathrm{X} 1 & : \text { Sharia Governance } \\
\mathrm{X} 2 & \text { : Firm Size }
\end{array}
$$

\section{HASIL PENELITIAN DAN PEMBAHASAN}

\section{IV.1. Hasil penelitian}

\section{Uji Validitas}

Uji validitas digunakan untuk mengukur bahwa instrumen yang digunakan dalam penelitian ini sesuai dengan apa yang seharusnya diukur dan mampu mengungkap sesuatu yang akan diukur oleh kuesioner tersebut. Suatu instrumen dikatakan valid jika pertanyaan pada kuesioner mampu untuk mengungkapkan sesuatu yang akan diukur oleh instrumen tersebut (Ghozali, 2009). Untuk dapat dikatakan valid apabila $r$ hitung lebih besar daripada $r$ tabel, ( $r$ hitung $>r_{\text {tabel }}$ ). Setiap item pernyataan pada variabel yang diteliti diperoleh $r$ hitung $>r$ tabel maka dapat disimpulkan bahwa setiap item pernyataan dinyatakan valid (lihat lampiran).

\section{Uji Reliabilitas}

Realibilitas adalah ukuran yang menunjukkan konsistensi dari alat ukur dalam mengukur gejala yang sama di lain kesempatan. Suatu instrumen dikatakan reliable atau handal jika jawaban seseorang terhadap pertanyaan adalah konsisten atau stabil dari waktu ke waktu (Ghozali, 2009). Jadi, realibilitas dimaksudkan untuk mengukur apakah instrumen yang digunakan dalam penelitian ini bebas dari kesalahan, sehingga akan memperoleh hasil yang konsisten dan akurat. Pengujian dilakukan dengan menggunakan teknik cronbach alpha. Dimana suatu instrumen dikatakan reliable apabila memiliki koefisien keandalan atau alpha sebesar (a) > 0,50 (Ghozali, 2005). Hasil uji realibilitas dapat dilihat pada table berikut:

Tabel 1

Uji Reliabilitas

\begin{tabular}{|c|c|c|c|}
\hline No & \multicolumn{1}{|c|}{ Variabel } & $\begin{array}{c}\text { Jumlah } \\
\text { Pertanyaaan }\end{array}$ & $\begin{array}{c}\text { Crombach } \\
\text { Alpha }\end{array}$ \\
\hline 1. & Sharia Governance $\left(\mathrm{X}_{1}\right)$ & 24 & 0,938 \\
\hline
\end{tabular}




\begin{tabular}{|c|l|c|c|}
\hline 2. & $\begin{array}{l}\text { Kinerja Lembaga Keuangan Syariah } \\
(\mathrm{Y})\end{array}$ & 15 & 0,951 \\
\hline
\end{tabular}

Sumber : Data Olahan

Dari tabel diatas memperlihatkan bahwa instrumen penelitian yang digunakan adalah reliable untuk semua variabel.

\section{Uji Normalitas Data}

Pada penelitian ini, pengujian normalitasnya menggunakan One Sample Kolmogorov Smirnov-Test. Uji ini digunakan untuk menguji asumsi normalitas data.

Tabel 2

Hasil Uji One-Sample Kolmogorov-Smirnov

\begin{tabular}{|l|c|}
\hline \multicolumn{1}{|c|}{ Keterangan } & Unstandardized Residual \\
\hline $\mathrm{N}$ & 18 \\
\hline Kolmogorov-Smirnov Z & 0.522 \\
\hline Asymp. Sig. (2-tailed) & 0.948 \\
\hline
\end{tabular}

Sumber: Data Olahan

Hasil analisis di atas nilai Kolmogorov-Smirnov sebesar 0,522 dengan signifikansi 0,948 > 0.05 untuk 18 sampel. Hal ini berarti residualnya terdistribusi secara normal, dengan demikian hipotesis nol tidak dapat ditolak.

\section{Uji Multikolinearitas}

Mendeteksi adanya multilolinearitas dilihat dari nilai VIF (Variance Inflation Factor) dan tolerance- nya. Nilai Cut-off yang umum dipakai adalah tolerance < 0,10 atau sama dengan nilai VIF > 10 (Ghozali, 2009:26). Tabel berikut ini memperlihatkan hasil output SPSS untuk mendeteksi multikolinearitas:

Tabel 3

Hasil Uji Multikoleniaritas

\begin{tabular}{|l|c|c|}
\hline \multicolumn{1}{|c|}{ Model } & Tolerance & VIF \\
\hline Sharia Governance & 0.862 & 1.160 \\
\hline Firm Size & 0.862 & 1.160 \\
\hline
\end{tabular}

Sumber: Data Olahan

Berdasarkan tabel diatas diperoleh nilai Tolerance $(1,000)$ dan VIF $(1,000)$ yang menunjukan bahwa nilai Tolerance dibawah 0,10 (nilai tolerance berkisar antara 0,991 sampai 0,999), begitu jug a dengan nilai VIF yang tidak ada diatas 10 (nilai VIF berkisar antara 1,001 sampai 1,009), sehingga terbukti tidak ada multikolinearitas yang serius.

\section{Uji Heterokedastisitas}


Uji Glejser merupakan salah satu cara untuk mendeteksi gejala heterokedastisitas dalam persamaan regresi. Uji Glejser meregres nilai absolut residual terhadap variabel independen. Bila variabel independen signifikan secara statisti $\mathrm{k}$ mempengaruhi variabel dependen, maka ada indikasi terjadinya heterokedastisitas. Tabel berikut ini memperlihatkan hasil uji heterokedastisitas:

Tabel 4

Hasil Uji Heterokedastisitas

\begin{tabular}{|l|c|c|c|}
\hline \multirow{2}{*}{\multicolumn{1}{|c|}{ Keterangan }} & \multicolumn{3}{c|}{ Unstandardized Residual } \\
\cline { 2 - 4 } & $\mathbf{T}$ & Significance & $\mathbf{N}$ \\
\hline (Constant) & 0.216 & 0.832 & \\
\hline Sharia Governance & 0.098 & 0.923 & 18 \\
\hline Firm Size & -1.282 & 0.219 & \\
\hline
\end{tabular}

Sumber: Data Olahan

Berdasarkan tabel diatas, terlihat bahwa nilai Sharia Governance sebesar 0.098 dan signifikansi $0.923>0.05$ dan untuk nilai firm size sebesar -1.282 dan signifikansi 0.219>0.05. Hal ini menunjukkan tidak terjadi heterokedastisitas karena nilai signifikansi dari hasil persamaan regresi berada di atas 0,05. Model persamaan regresi penelitian ini layak untuk digunakan dalam penelitian.

\section{Uji Autokorelasi}

Mendeteksi autokorelasi adalah dengan uji Durbin Watson. Pengujiannya sebagai berikut:

$$
\begin{array}{ll}
\mathrm{d}<\mathrm{dL} & \text { : terdapat gejala autokorelasi positif } \\
\mathrm{d}>(4-\mathrm{dL}) & \text { : terdapat gejala autokorelasi negatif } \\
\mathrm{dL}<\mathrm{d}<(4-\mathrm{dU}) & : \text { tidak terdapat gejala autokorelasi } \\
\mathrm{dL}<\mathrm{d}<\mathrm{dU} & \text { : pengujian tidak meyakinkan }
\end{array}
$$

Tabel 5

Hasil Uji Autokorelasi

\begin{tabular}{|c|c|c|c|}
\hline Model & R & R Square & Durbin-Watson \\
\hline Sharia Governance dan Firm Size & $0.838^{\mathrm{a}}$ & 0.703 & 1.597 \\
\hline
\end{tabular}

Sumber: Data Olahan

Pengujian Durbin - Watson untuk Sharia Governance dan firm Size adalah 1,597 dengan signifikansi 5\% dan sampel sebesar 18 . Nilai d terletak di antara batas atas $(\mathrm{du}=1,391)$. Nilai DW $(1,597)$ lebih besar dari batas atas (du) 2,609 dan kurang dari 1,391 (4- du), maka disimpulkan bahwa dalam persamaan regresi ini tidak terdapat autokorelasi.

\section{IV.2. Hasil Pengujian Hipotesis}

Penelitian ini membahas beberapa variabel yaitu: Variabel Dependen adalah Kinerja Lembaga Keuangan Syariah, Variabel Independen adalah 
Sharia Governance dan Variabel Pemoderasi adalah Firm Size. Penelitian ini menggunakan persamaan regresi dan ketepatan fungsi regresi dalam menaksir nilai aktual dapat diukur dari goodness of fit. Secara statistik dapat diukur nilai koefisien determinasi, nilai statistik F dan nilai statistik t (Ghozali, 2009:14).

\section{Koefisien determinasi $\left(R^{2}\right)$}

Penelitian ini menggunakan koefisien determinasi untuk mengukur seberapa jauh kemampuan model dalam menerangkan variasi variabel dependen. Nilai koefisien determinasi adalah antara nol dan satu. Hasil uji goodness of fit disajikan pada tabel berikut ini:

Tabel 6

Hasil Uji Goodness of fit

\begin{tabular}{|c|c|r|r|r|}
\hline Model & $\mathbf{R}$ & $\begin{array}{c}\text { R } \\
\text { Square }\end{array}$ & $\begin{array}{c}\text { Adjusted R } \\
\text { Square }\end{array}$ & \multicolumn{2}{|c|}{$\begin{array}{c}\text { Std. Error of the } \\
\text { Estimate }\end{array}$} \\
\hline Sharia Governance & $0.827 \mathrm{a}$ & 0.684 & 0.664 & 0.195 \\
\hline $\begin{array}{c}\text { Sharia Governance } \\
\text { Firm Size }\end{array}$ & $0.435 \mathrm{a}$ & 0.189 & 0.139 & 0.313 \\
\hline
\end{tabular}

Sumber: Data Olahan

Berdasarkan hasil diatas, maka koefisien determinasi 0.684 yang berarti bahwa variabel independen (sharia Governance) dapat menjelaskan variabel dependen (Kinerja Lembaga Keuangan Syariah) sebesar 68.4\% sementara itu $31.6 \%$ dijelaskan oleh faktor lain. Kemudian koefisien determinasi untuk variabel independen (sharia Governance) dan variabel pemoderasi (Firm Size) senilai 0.189 atau hanya $18.9 \%$ yang dapat menjelaskan variabel dependen (Kinerja Lembaga Keuangan Syariah) sementara itu 81,1\% dijelaskan oleh faktor lain.

\section{Uji Statistik F}

Uji statistik $\mathrm{F}$ adalah untuk menunjukan apakah variabel independen dan variabel pemoderasi sudah cukup kuat untuk memprediksi variabel dependen. Tabel berikut ini merupakan hasil uji F:

Tabel 7

Hasil Uji Statistik F

\begin{tabular}{|l|l|r|r|r|r|c|}
\hline \multicolumn{1}{|c|}{ Model } & & $\begin{array}{c}\text { Sum of } \\
\text { Squares }\end{array}$ & df & $\begin{array}{c}\text { Mean } \\
\text { Square }\end{array}$ & F & Sig. \\
\hline $\begin{array}{l}\text { Sharia } \\
\text { Governance } \\
\text { * Firm Size }\end{array}$ & Regression & 1.320 & 1 & 1.320 & 34.575 & $0.000^{\mathrm{a}}$ \\
\cline { 2 - 8 } & Residual & .611 & 16 & 0.038 & & \\
\cline { 2 - 8 } & Total & 1.931 & 17 & & & \\
\hline
\end{tabular}

Sumber: Data Olahan 
Dari tabel 8 diperoleh nilai $\mathrm{F}$ untuk variabel independen (Sharia Governance) dan variabel pemoderasi (Firm Size) sebesar 34.575 dan signifikansi sebesar $0.000<0.05$ terhadap variabel dependen (Kinerja). Hasil ini menunjukkan bahwa variabel independen dan variabel pemoderasi memprediksi variabel dependen.

\section{Uji Signifikan Parameter Individual (Uji Statistik t)}

Menguji seberapa jauh pengaruh satu variabel independen secara individual dalam menerangkan variasi variabel dependen dilakukan dengan uji statistik t (Ghozali, 2009:17). Hasil uji t ditampilkan dalam tabel berikut:

Tabel 8

Hasil Uji Statistik t

\begin{tabular}{|c|c|c|c|c|}
\hline \multirow{2}{*}{ Model } & \multicolumn{2}{|c|}{ Unstandardized Coefficients } & \multirow{2}{*}{$\mathbf{t}$} & \multirow{2}{*}{ Sig. } \\
\hline & $\mathbf{B}$ & Std. Error & & \\
\hline Constant & -0.072 & 0.924 & -0.078 & 0.939 \\
\hline Sharia Governance & 1.018 & 0.200 & 5.088 & 0.000 \\
\hline $\begin{array}{l}\text { Sharia Governance } \\
\text { * Firm Size }\end{array}$ & -0.000009889 & 0.000 & -1.933 & 0.071 \\
\hline
\end{tabular}

Sumber: Data Olahan

\section{IV.3. Pembahasan Hasil Penelitian}

Berdasarkan pengujian yang telah dilakukan diatas, maka berikut ini akan dibahas pengaruh variabel independen berupa sharia governance terhadap variabel dependen berupa Kinerja Lembaga Keuangan Syariah.

\section{Pengaruh Sharia Governance terhadap Kinerja Lembaga Keuangan Syariah.}

Penelitian ini memprediksi pengaruh variabel independen (Sharia Governance) terhadap variabel dependen (Kinerja Lembaga Keuangan Syariah). Pada hasil pengujian regresi, Sharia Governance berpengaruh terhadap Kinerja Lembaga Keuangan Syariah. Hasil penelitian ini menunjukkan bahwa sharia governance mampu mempengaruhi kinerja lembaga keuangan syariah di Provinsi Riau yang dibuktikan dengan koefisien sebesar 5,008 dengan tingkat signifikansi sebesar 0,000 jauh lebih kecil dibandingkan dengan nilai $\alpha(0,05)$. Hal ini menunjukkan bahwa sharia governance mampu mempengaruhi kinerja lembaga keuangan syariah.

Hasil ini konsisten dengan teori-teori serta hasil penelitian sebelumnya yang menyatakan bahwa semakin tinggi penerapan good corporate governance maka semakin meningkatkan kinerja perusahaan tersebut. Penelitian Labelle (2002) menyebutkan corporate governance berhubungan positif dengan kinerja perusahaan di mata investor. Pernyataan ini didukung oleh survei yang dilakukan oleh McKinsey (2001) yang menunjukkan bahwa 
investor di Indonesia bersedia membayar biaya yang lebih tinggi untuk perusahaan yang sudah memeliki tata kelola yang baik.

Hasil penelitian ini menguatkan bahwa penerapan governance syariah pada perbankan syariah lebih mengarah pada prinsip syariah, dan berbeda dengan penerapan governance pada perbankan konvensional. Menurut Algoud dan Lewis (1999) permasalahan governance dalam perbankan syariah ternyata sangat berbeda dengan perbankan konvensional. Serta penerapan tata kelola perusahaan syariah yang baik (Good Governance Syariah) akan meningkatkan kinerja perusahaan syariah tersebut.

Sharia governance merupakan suatu sistem yang mengatur dan mengendalikan manajer agar dapat memberikan dan meningkatkan nilai lembaga keuangan perbankan syariah kepada para pemegang saham dan stakeholder. Penerapan praktik sharia governance dapat membantu para investor atau stakeholder untuk mengetahui bahwa manajer telah bertindak untuk mengelola perbankan syariah sebagaimana mestinya. Sharia governance juga dapat memberikan sinyal yang baik kepada investor dan menilai perusahaan dengan lebih tinggi.

Dengan mengunakan dimensi sharia governance, pada perbankan syariah lebih dapat menggambarkan keadaan pengelolaan syariah pada perbankan syariah. Hal ini dapat dilihat dan dianalisa dari masing-masing dimensi dari sharia governance tersebut, sebagai berikut:

a. Shiddiq (Kejujuran)

Shiddiq artinya benar dalam perkataannya dan perbuatannya. Dalam praktik perbankan syariah, kejujuran harus diterapkan dalam setiap transaksi perbankan. Karyawan bank dilarang memanfaatkan bank untuk kepentingan pribadinya, mendahului kepentingan nasabah dan tidak menyembunyikan kelemahan produk perbankan sehingga nantinya nasabah tidak merasa dirugikan.

b. Amanah (Pemenuhan Kepercayaan)

Amanah artinya benar-benar bisa dipercaya. Dalam praktik perbankan syariah bahwa Bank harus meyakini bahwa semua anggota organisasi bank mempunyai kompetensi sesuai dengan fungsi dan tugasnya sehingga bisa menjalankan tugas dan fungsinya dengan sebaik-baiknya.

c. Tabligh (Transparansi dan Keterbukaan)

Tabligh artinya menyampaikan. Tidak ada yang disembunyikan meski itu menyinggung. Dalam praktik perbankan syariah bahwa bank harus mengungkapkan informasi tepat waktu, memadai, jelas, akurat, dan dapat diperbandingkan, serta mudah diakses oleh stakeholders sesuai dengan haknya. Informasi yang harus diungkapka meliputi visi misi, tujuan organisasi, strategi, kondisi keuangan, struktur organisasi dan system reward dan punishment, pemegang saham mayoritas. Prinsip keterbukaan yang dianut oleh bank tidak mengurangi kewajiban untuk memenuhi ketentuan rahasia bank sesuai dengan peraturan perundang-undangan yang berlaku, rahasia jabatan, dan hak-hak pribadi. Kebijakan bank harus tertulis dan dikomunikasikan kepada pihak yang berkepentingan 
(stakeholders) dan yang berhak memperoleh informasi tentang kebijakan tersebut.

d. Fathonah (Kecerdasan)

Fathonah artinya cerdas dalam menyampaikan, menjelaskan, mengatur dan mengelola sesuatu. Dalam praktik perbankan syariah bahwa bank harus mampu menjelaskan dan menyampaikan informasi tentang produknya dengan baik sehingga calon nasabah paham dan mengerti dan akan percaya terhadap bank tersebut untuk mengatur dan mengelola dana mereka.

e. Tawazun (Keseimbangan)

Tawazun adalah keseimbangan dalam segala hal dan ini merupakan karakter dari ahlusunnah wal jamaah yang selalu diajarkan oleh Nabi Muhammad SAW dan para sahabat. Dalam praktik perbankan syariah bahwa karakteristik keseimbangan bank syari'ah menyatakan Prinsip syari'ah Islam dalam pengelolaan harta menekankan keseimbangan (tawazun) yang esensinya meliputi keseimbangan aspek material dan spiritual, aspek private dan publik, sektor keuangan dan sektor riel, bisnis dan sosial, dan keseimbangan aspek pemanfaatan dan pelestarian. Transaksi syariah tidak hanya menekankan pada maksimalisasi keuntungan perusahaan semata untuk kepentingan pemilik (shareholder). Manfaat yang didapatkan dari transaksi tersebut tidak hanya difokuskan pada pemegang saham, akan tetapi pada semua pihak yang dapat merasakan manfaat adanya suatu kegiatan ekonomi. Bank harus memberikan kesempatan kepada seluruh stakeholders untuk memberikan masukan dan menyampaikan pendapat bagi kepentingan bank serta mempunyai akses terhadap informasi sesuai dengan prinsip keterbukaan.

f. Mas'uliyah (Akuntabilitas)

Mas'uliyah adalah akuntabilitas yang merupakan prinsip kepemimpinan. Dalam praktik perbankan syariah bahwa Bank harus menetapkan tanggung jawab yang jelas dari masing-masing organisasi yang selaras dengan visi, misi, sasaran usaha dan strategi perusahaan. Bank harus memastikan terdapatnya check and balance system dalam pengelolaan bank. Bank harus memiliki ukuran kinerja dari semua jajaran bank berdasarkan ukuran-ukuran yang disepakati konsisten dengan nilai perusahaan (corporate values), sasaran usaha dan strategi bank serta memiliki rewards and punishment system.

g. Akhlaq (Moral dan Integritas)

Akhlak atau moral merupakan suatu tindakan yang mendorong seseorang untuk bertindak secara baik. Dalam praktik perbankan syariah bahwa bank memberikan informasi tentang keunggulan dan kelemahan produk dan tidak membedakan pelayanan atas dasar suku, agama, ras, dan golongan.

h. 'Adalah (Keadilan)

'Adalah merupakan keadilan dalam bersikap. Dari dasar mekanisme keuangan syari'ah tersebut akan mampu mewujudkan kegiatan ekonomi 
yang lebih adil dan transparan. Dalam praktik perbankan syariah bahwa Mekanisme keuangan dalam bank syari'ah diharapkan dapat menghilangkan dampak negative spread atau keuntungan minus dan Mekanisme keuangan bank syari'ah tidak mengenal konsep nilai waktu dari nilai (time value of money) (Syafei Antonio, 2001). Adil dalam memberikan informasi dengan cara tidak menutupi kelemahan produknya.

i. Hurriyah (Independensi dan Kebebasan yang Bertanggungjawab) Huriyyah adalah sikap yang beranggapan bahwa manusia merupakan ciptaan Tuhan dan memiliki kebebasan yang bertanggungjawab. Dalam praktik perbankan syariah bahwa Bank harus menghindari terjadinya dominasi yang tidak wajar oleh stakeholder manapun dan tidak terpengaruh oleh kepentingan sepihak serta bebas dari benturan kepentingan (conflict of interest), Bank dalam mengambil keputusan harus obyektif dan bebas dari segala tekanan dari pihak manapun.

j. Ihsan (Profesional)

Ihsan adalah kesempurnaan atau terbaik, profesional dalam menjalankan tugas. Dalam praktik perbankan syariah bahwa dalam melakukan pelayanan terhadap nasabah dengan cara tidak membedakan ras, suku dan agama dan menganggap bahwa nasabah merupakan seorang raja yang harus dilayani dengan baik.

k. Wasathan (Kewajaran)

Wasathan adalah kewajaran dalam segala hal. Dalam praktik perbankan syariah bahwa Bank harus senantiasa memperhatikan kepentingan seluruh stakeholders berdasarkan azas kesetaraan dan kewajaran (equal treatment).

l. Ghirah (Semangat)

Ghirah adalah semangat dalam membela yang benar. Dalam praktik perbankan syariah bahwa bank harus menjelaskan dengan sebaikbaiknya dan sejujur-jujurnya tentang akad yang terjadi dalam suatu transaksi tanpa ada yang ditutupi.

m. Idarah (Pengelolaan)

Idarah adalah mampu mengelola semua hal dengan baik. Bahwa dalam praktik perbankan syariah bahwa Bank selaku lembaga keuangan untuk penghimpun dana mampu mengelola dana nasabah dengan baik sesuai dengan syariah Islam dan sesuai dengan akad pada awal transaksi, serta untuk mewujudkan sistem dan tatanan perbankan syariah yang sehat dan istiqomah dalam penerapan prinsip syariah dibutuhkan Sumber Daya Insani (SDI) yang mampu menguasai syari'ah dan teknis perbankan.

n. Khilafah (Kepemimpinan)

Khilafah adalah kepemimpinan dalam Islam, mampu memimpin secara keseluruhan. Pada praktik perbankan syariah bahwa pimpinan bank mampu memimpin bawahan dalam melaksanakan fungsi dan tugasnya sehingga bank mampu bertahan dan memiliki kinerja yang baik.

o. Aqidah (Kepercayaan dan Keyakinan) 
Aqidah adalah kepercayaan dan keyakinan yang teguh. Pada praktik perbankan syariah bahwa Perbankan syari'ah tidak hanya terfokus pada pencapaian target yang ditetapkan demi kepentingan shareholders, tetapi juga berkomitmen pada penerapan nilai-nilai syari'ah.

p. Ijabiyah (Berfikir Positif) Ijabiyah adalah berfikir positif dan tidak menganggap sesuatu hal menjadi tidak penting. Pada praktik perbankan syariah bahwa Bank harus mampu melindungi dana nasabah dan bank harus menerapkan prinsip kehatihatian dalam menyalurkan dana nasabah.

q. Raqabah (Pengawasan), Raqabah adalah prinsip yang menganggap bahwa setiap tindakan itu diawasi. Pada praktik perbankan syariah bahwa organisasi perbankan syariah dalam hal ini Dewan Pengawas Syariah (DPS) harus melakukan pengawasan terhadap praktik perbankan syariah dan memegang prinsip bahwa praktik tersebut tidak hanya diawasi oleh manusia saja tetapi diawasi juga oleh Allah SWT.

r. Qira'ah Dan Ishlah (Organisasi Yang Terus Belajar dan Selalu Melakukan Perbaikan)

Qira'ah dan Ishlah adalah organisasi yang terus belajar dan selalu melakukan perbaikan. Pada praktik perbankan syariah bahwa Perbankan syariah harus melakukan pernyempurnaan baik dari segi organisasi maupun dari segi produk yang sesuai syariah. Perbankan syariah harus mampu mengoreksi hal yang sudah menyimpang dari prinsip syariah.

s. Zuhud (menghindari hal-hal keduniawian)

Zuhud adalah menganggap bahwa dunia bukan segala-galanya tetapi ada akhirat yang kekal. Pada praktik perbankan syariah bahwa dalam pencapaian target, Perbankan syariah tidak boleh menghalalkan segala cara sehingga perbankan syariah terhindar dari hal-hal yang dilarang Islam.

\section{Pengaruh Sharia Governance terhadap Kinerja Lembaga Keuangan Syariah yang dimoderasi oleh Firm Size}

Penelitian ini memprediksi pengaruh variabel independen (Sharia Governance) terhadap variabel dependen (Kinerja Lembaga Keuangan Syariah) dan dimoderasi oleh firm size. Pada hasil pengujian regresi, sharia governance tidak berpengaruh terhadap Kinerja Lembaga Keuangan Syariah dengan variabel moderasi oleh firm size. Hasil penelitian ini menunjukkan bahwa sharia governance tidak mampu mempengaruhi kinerja lembaga keuangan syariah di Provinsi Riau setelah dimoderasi oleh firm size dibuktikan dengan koefisien sebesar-1,933 dengan tingkat signifikansi sebesar 0,071 lebih besar dibandingkan dengan nilai $\alpha(0,05)$. Hal ini menunjukkan bahwa sharia governance tidak mampu mempengaruhi kinerja lembaga keuangan syariah setelah dimoderasi oleh firm size. Dalam penelitian ini, firm size diproksikan dengan jumlah karyawan (Dini dan Djoko, 2012). 
Dari pengujian hipotesis diatas, diperoleh hasil bahwa firm size yang diproksikan oleh jumlah karyawan tidak mampu mempengaruhi sharia governance dan kinerja lembaga keuangan syariah. Jadi, variabel moderasi ini tidak mampu mempengaruhi variabel independen dan variabel dependen. Untuk penelitian berikutnya bisa menggunakan variabel moderasi yang lain dan firm size hendaknya menggunakan proksi yang lain. Sedangkan ketika firm size mampu berpengaruh positif signifikan terhadap kinerja keuangan perusahaan sesuai dengan penelitian yang dilakukan oleh Hesti (2010) dan Uyun (2010).

\section{KESIMPULAN}

Dari hasil pengujian hipotesis diperoleh hasil bahwa penelitian ini menunjukkan bahwa sharia governance mampu mempengaruhi kinerja lembaga keuangan syariah di Provinsi Riau yang dibuktikan dengan koefisien sebesar 5,008 dengan tingkat signifikansi sebesar 0,000 jauh lebih kecil dibandingkan dengan nilai $\alpha(0,05)$. Hal ini menunjukkan bahwa sharia governance mampu mempengaruhi kinerja lembaga keuangan syariah. Kemudian hasil penelitian ini menunjukkan bahwa sharia governance tidak mampu mempengaruhi kinerja lembaga keuangan syariah di Provinsi Riau setelah dimoderasi oleh firm size dibuktikan dengan koefisien sebesar -1,933 dengan tingkat signifikansi sebesar 0,071 lebih besar dibandingkan dengan nilai $\alpha(0,05)$. Hal ini menunjukkan bahwa sharia governance tidak mampu mempengaruhi kinerja lembaga keuangan syariah setelah dimoderasi oleh firm size.

Penelitian ini dapat membuktikan bahwa sharia governance pada perbankan Syariah mampu lebih mencerminkan kinerja pada perbankan Syariah tersebut, dengan mengunakan dimensi syariah berupa: Shiddiq (kejujuran), Amanah (Pemenuhan Kepercayaan), Tabliqh (Transparansi dan Keterbukaan), Fathonah (kecerdasan), Tawazun (keseimbangan), Mas'uliyah (akuntabilitas), Akhlaq (Moral dan Integritas), 'Adalah (Keadilan), Hurriyah (Independensi dan Kebebasan yang Bertanggungjawab), Ihsan (Profesional), Wasathan (Kewajaran), Ghirah (Semangat), Idarah (Pengelolaan), Khilafah (Kepemimpinan), Aqidah (Kepercayaan dan Keyakinan), Ijabiyah (Berfikir Positif), Raqabah (Pengawasan), Qira'ah Dan Ishlah (Organisasi Yang Terus Belajar dan Selalu Melakukan Perbaikan) dan Zuhud (menghindari hal-hal keduniawian).

\section{REFERENSI}

Archer, S., \& Karim, R. A. A. (1997). Agency theory, corporate governance, and the accounting regulation of Islamic banks. Research in Accounting Regulation, Suppl. 1, 97 - 114.

Abdussalam Mahmoud Abu-Tapanjeh, (2009), Corporate governance from the Islamic perspective: A comparative analysis with OECD principles, Critical Perspectives on Accounting 20. 556-567. 
Aznan, (2002), Optimal Shariah Governance In Islamic Finance, http://www.nzibo.com/IB2/04_01.pdf (10-12-2012)

Black, B., Jang, H., dan Kim, W. (2003) : Does Corporate Governance Affect Firm Value? Evidence from Korea, Research Paper Series,, KDI School of Public Policy and Management, 05/11.

Che Haat, Mohd Hassan, Rashidah A.R. And Sakthi M. (2008). Corporate Governance, Transparency and Performance of Malaysian Companies. Managerial Auditing Journal Vol. 23 No. 8 pp. 744-778.

Darmawati, Deni dkk.(2004). Hubungan Corporate Governance dan Kinerja Perusahaan. Symposium Nasional Akuntansi VII, Denpasar, 2-3 Desember 2004.

Dini, Joko., (2012) Pengaruh Struktur Kepemilikan, Ukuran Perusahaan, dan Corporate Governance terhadap Manajemen laba, Jurnal Prestasi Vol.9 No.1

Ghozali, Imam, 2009. Aplikasi Analisis Multivariate Dengan Program SPSS, Edisi Keempat, Penerbit Universitas Diponegoro.

Grant, Garry H., (2003), The Evolution of Corporate Governance and Its Impact to Modern Corporate America, Management Decisions, 41, 9, 923-934.

Hasan Turabi, (1987), Principles Bank Indonesia, Directorate of Islamic Banking of Governance, Freedom, and Responsibility in Islam, The American Journal of Islamic Social Sciences l Vol. 4, No. 1

Hutagalung, D. (2004) : Pengaruh Penerapan Prinsip-Prinsip Good Corporate Governance dan Sumber Keunggulan terhadap Kinerja Keuangan: Suatu Analisis Terhadap BUMN di Indonesia, Disertasi, Universitas Padjadjaran, Bandung

Hermanson, Dana R., and Larry E. Rittenberg, (2003), "Chapter 2, Internal Audit and Organizational Governance", Research Opportunities in Internal Auditing, The Institute of Internal Auditor Foundation, pp. 2671)

Hesti, Diah Aristya (2010). Analisis Pengaruh Ukuran Perusahaan, Kecukupan Modal, Kualitas Aktiva Produktif (Kap), dan Likuiditas terhadap Kinerja Keuangan.Undergraduate thesis (unpublished), Universitas Diponegoro

Kaplan, Robert and David P.Norton. 1996, The strategy Focused Organization, Boston. Massachusetts. Hrvard Business School Press

Nofianti, Leny. et.al (2012) "Principles Of Good Corporate Governance Shari'a Model", Proceeding ICIAF

Nofianti, Leny.dan Irfan, Andi (2013) "Hubungan Antara Penerapan Model Prinsip-Prinsip Good Governance Syari'ah Dengan Kinerja Lembaga Keuangan Syariah", Proceeding Simposium Nasional Akuntansi Syariah

Lewis, M. K. and Algaud, L. M., (2001), Islamic Banking. Edward Elgar, Cheltenham, UK.

Maria Bhatti and M. Ishaq Bhatti , (2010), Toward Understanding Islamic Corporate Governance Issues in Islamic Finance, Asian Politics \& Policy Volume 2, Issue 1, pages 25-38, January/March 
Masri Singarimbun, dan Syofyan Effendi. 1995. Metode Penelitian Survey. Lembaga Penelitian dan pengembangan Ekonomi dan Sosial, Jakarta.

Nasser M. Suleiman, (2000), Corporate governance in Islamic banks, http://sukuk.me/library/education/governance.pdf. (7-12-2012)

Nur hidayati setyani, (2010), Kebijakan pemerintah tentang pelaksanaan prinsip "good corporate governance" bagi bank umum dalam praktek perbankan syari'ah, program pascasarjana universitas diponegoro Semarang.

Outlook Perbankan Syari'ah, 2013.

Sulistyanto, S. (2003) : Good Corporate Governance: Bisakah Meningkatkan Kepercayaan Masyarakat?, Jurnal Ekonomi \& Bisnis-EKOBIS, 4, 1, http:// artikel.us//hsulistyanto1.html.

Sukrisno Agoes, (2005), Penerapan GCG Pada Perguruan Tinggi. Auditor, No. 18

Undang-undang No. 21 Tahun 2008 tentang Perbankan Sharia, pasal 34, 35, 38 dan 39.

Uyun, Shofwatul (2011). Pengaruh Manajemen Risiko, Ukuran Perusahaan, dan Leverage terhadap Kinerja Keuangan Perusahaan pada Perusahaan Manufaktur yang Terdaftar di Bursa Efek Indonesia. Undergraduate thesis (unpublished), Universitas Airlangga.

Thompson, P. dan Hung, C.A. (2002) : Cracking the Singapore Code of Corporate Governance: a Step Corporate Governance Towards World Class Corporate Governance and Superior Performance?, Research Paper Series, The Centre for Europe Asia Business Research, 9.

Zulkifli Hasan, (2009), Corporate Governance : Western and Islamic Perspectives, International Review of Business Research Papers, Vol.5 No. 1 January 2009 Pp. 277-293. 